\title{
Immunomodulator Activity of Ethanol Extract of Tapak Liman Leaves (Elephantopus scaber Linn.)
}

\author{
Yufri Aldi*, Dwisari Dillasamola, Gita Rahma Yanti
}

Yufri Aldi*, Dwisari Dillasamola, Gita Rahma Yanti

\section{${ }^{1}$ Faculty of Pharmacy, Department of} Pharmacology, Universitas Andalas, Padang, INDONESIA.

\section{Correspondence \\ Yufri Aldi}

Faculty of Pharmacy, Department of Pharmacology, University Andalas, Padang, INDONESIA

E-mail: yufrialdi@phar.unand.ac.id

History

- Submission Date: 21-08-2019;

- Review completed: 28-08-2019;

- Accepted Date: 17-09-2019.

DOI : 10.5530/pj.2019.11.220

Article Available online http://www.phcogj.com/v11/i6s

\section{Copyright}

(C) 2019 Phcogj.Com. This is an open access article distributed under the terms of the Creative Commons Attribution 4.0 International license.

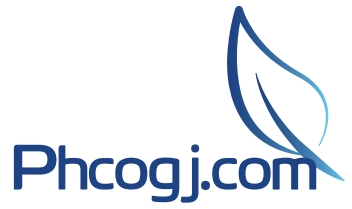

\begin{abstract}
Introduction: Tapak Liman (Elephantopus scaber Linn) is a medicinal plant in Indonesia which traditionally used as a treatment for fever, gout, dysentery, hepatitis, and infections. Aim: This study aims to determine the immunostimulants activity of tapak liman extract with carbon clearance method and to determine the percentage and total leukocytes and relative lymph weights. Materials and Methods: Twenty white male mice divide assigned to 1 control group and 3 experimental groups. It treated by oral administration of tapak liman extract; 10, 30, and $100 \mathrm{mg} / \mathrm{kgBW}$. After six days of administration, mice intravenously injected with $0.1 \mathrm{ml} / 10 \mathrm{gBW}$ colloidal carbon. Blood obtained from the mice tail at; 3rd, 6th, 9th, 12th and 15th minutes. The determined absorbance then calculated to obtain the phagocytotic index, the percentage and the total of leukocyte cells and lymph weights. Results: Phagocytosis index increased significantly at 1, 12, 1.24 and 1.47 . The percentages of neutrophil segment are $57 \%, 60 \%$ and $60 \%$, for lymphocytes are 3,80\%,32.80\% and $34.20 \%$, monocyte cells are $4.60 \%, 3.00 \%$ and $2.60 \%$, neutrophil are $3.40 \%, 3.20 \%, 2.20 \%$, and for the eosinophil cells are $3.20 \%, 1.8 \%$ and $1.20 \%$. Total leukocyte cells are 10,760,11,630 and 15,880 cells/microliter. The relative lymph weight of each dose in the sequence is $0.36,0.49$ and 0.66 . Conclusion: Ethanol extract of tapak liman leaves (Elephantopus scaber Linn) can increase the immunity of mice. Key words: Elephantopus scaber Linn., Immunomodulator, Carbon clearance, Lymph, Leucocytes.
\end{abstract}

\section{INTRODUCTION}

Modern lifestyle making changes in some parts of people's lives, such as the tendency to consume junk food, lack of exercise and high levels of stress that causes the immune system drops. These conditions make pathogenic microbes such as viruses, bacteria, protozoa, and fungi could easily attack the body then infected by various infectious diseases and degenerative diseases that cause death. ${ }^{1}$ Based on the World Health Organization (WHO) data, in 2016 as many as 10.4 million people suffered from tuberculosis $(\mathrm{TB})$ and 1.7 million people died. More than $95 \%$ of TB patients died in developing countries. Another example HIV/AIDS, as many as 1 million people died and as many as 1.8 million new people are infected with HIV. ${ }^{2}$

Based on these data it can be concluded that happened because the body's immune system drops. An effort need to be made in order to increase the body's immune system. The immune system is the most important part of the body's defence mechanism. The human body is capable of defending itself from infections caused by microorganisms because of this system. The immune system can be divided into two types, nonspecific immune system and specific immune system. $^{3}$

The non-specific immune system is a first-line body defence from microorganisms attack. This defence can be physical (skin), biochemistry (complement, lysozyme, and interferon), and cellular (neutrophil, monocytes, and macrophages). If the innate immune system or the nonspecific immune system is unable to cope with antigen attacks, the specific immune system (adaptive immunity) will work to produce antibodies. ${ }^{4}$ The immunomodulatory compounds can be used to improve or to restore the body's immune system. ${ }^{5}$

Immunomodulators help the body to optimize the immune system function that plays a significant role in the body's defence mechanism. Immunomodulators work in three ways; immunorestoration, immunostimulation, and immunosuppression. ${ }^{6}$ Immunomodulator comes from a natural or synthetic source. Plants are essential components in complementary medicine and alternative medicine because plants produce secondary metabolites such as alkaloids, steroids, and phenolics which can restore health and cure various diseases. ${ }^{7}$

Based on a few research, some plants having immunomodulatory activity ${ }^{5}$. One type of medicinal plant that is beneficial to health is the tapak liman plant (Elephantopus scaber Linn) from the Asteraceae family. This plant is widespread in the tropics such as in America, Africa, and Asia. Tapak Liman grows wild with other herbaceous plants. ${ }^{8}$ Tapak Liman contains chemical compounds like deoxyelephantopin, dihydrodeoxyelephantopin, stigmasterol lupeol, epifriedelinol. ${ }^{9}$ The latest research results show that the Liman Tread Leaf Extract can increase the haematopoetic process in anemic white male mice. ${ }^{10}$

The activities of tapak liman should be tested by immunomodulatory test, leukocyte determines the percentage and total leukocytes and relative lymph 
weights. It could be known these plants are immunostimulant so it could increase the body's immune system to defend the body from pathogenic microbes (viruses, bacteria, protozoa, and fungi). So based on that circumstances, Tapak Liman leaves could be an alternative drug because the availability of this plant was abundant so it is easy to get, cheap, and easy to process.

\section{MATERIALS AND METHODS}

\section{Place and time}

The research was conducted in September 2018-Januari 2019 at Laboratory Serology and Immonology Faculty Pharmacy, Laboratory Central of Faculty Pharmacy and Laboratory Biomedic Faculty of Medicine Universitas Andalas.

\section{Tools and materials}

This study used maceration bottles, funnels (Pyrex), $1 \mathrm{ml}$ syringes (Terumo), measuring pipettes (Pyrex), beaker glass (Pyrex), animal scales, analytic scales, stopwatches, micropipette (Eppendorf), measuring cups (Pyrex), volumetric flask (Pyrex), Erlenmeyer (Pyrex), leukocyte pipette (Assistent), hemometer (Assistent), rotary evaporator (Buchi), spectrophotometer UV-Visible (Genesys 10S UVVIS), microscope (Zeiss Primo Star) and microscope cameras (Zeiss Axiocam Erc 5s 105 Color).

The materials in this study were tapak liman leaves (Elephantopus scaber Linn), distilled water, $0.9 \% \mathrm{NaCl}$ (Widatra), ethanol (Brataco), hexane (Brataco), ethyl acetate (Brataco), methanol (B rataco), Giemsa (Merck), Chinese ink (Yamura), acetic acid (Merck), Turk reagent (St. Reagensia), and pure deoxyelephantopin compound.

\section{Extracting and characterization}

\section{Sampling}

The sample that used for this study was fresh tapak liman leaves (Elephantopus scaber Linn) taken at Universit as Andalas, Limau Manis, Padang. Fresh leaves are sorted, cut into small pieces and dried in a greenhouse. The dried leaves are mashed. 1070 gram dry powder of tapak liman leaves to use in this experiment. ${ }^{11}$

\section{Plant identification}

The plant was identified in Herbarium Andalas (ANDA), Department of Biology, Faculty of Mathematics and Natural Sciences, Universitas Andalas.

\section{Making extracts}

The total of $1070 \mathrm{~g}$ tapak liman leaves (Elephantopus scaber Linn) powder, macerated using $70 \%$ ethanol. Macerated in six hours and stirring occasionally, then let stand for 18 hours, and filtered. This process was repeated 3 times. Filtration result is collected and concentrated using a rotary evaporator to obtain the extract. ${ }^{11}$

\section{Organoleptic examination}

An organoleptic examination that conducted were shape, color, taste, and odor.

\section{Drying shrinkage}

Determination of drying shrinkage aims to show the maximum limit lost compounds in the drying process. Porcelain cup is heated in oven $105^{\circ} \mathrm{C}$ for 30 minutes, then cooled in a desiccator and weighting (w0). Put in 1 gram extract and weighting(w1). Heat in 1 hour at $105^{\circ} \mathrm{C}$, cool it in a desiccator then weigh it again. ${ }^{11}$

\section{Profile of thin layer chromatography tapak liman leaves extract}

Tapak Liman extract was dissolved in methanol then spotted with capillary on an aluminum silica gel plate 60 F254. The mobile phase used was n-hexane, ethyl acetate, and methanol (5:5:1). Observed under ultraviolet light at $254 \mathrm{~nm}$.

\section{Immunomodulatory activity testing}

Mice divide into four groups. Control group was given $0.5 \% \mathrm{Na}$ CMC, another three groups were given tapak liman leaves extract. The preparation of the test was carried out orally once a day for 6 days. On the seventh day after administration, blood was taken in the tail capillary. Mice blood was taken in the 3rd, 6th, 9th, 12th, and 15th minutes after carbon injection, $25 \mu$ of blood was taken and added $4 \mathrm{ml}$ of $1 \%$ acetic acid. Absorption was measured at a wavelength of $650 \mathrm{~nm}$. The mice that have been tested for carbon clearance were sacrificed, the lymph was taken and weighed.

\section{Percentage of leukocyte types}

One drop of blood is dripped on the object glass and leveled with another object glass, then dried. After drying, add the methanol to coat the whole blood smear and then leave it for 5 minutes. Add 1 drop of Giemsa solution which has been diluted with distilled water (1:20), left for 20 minutes, rinsed with distilled water, dried. Calculate the number of eosinophil cells, stem neutrophils, segment neutrophils, lymphocytes and monocytes under a microscope at 40X.

\section{Total leukocyte cell with haemocytometer}

Fresh blood is sucked with a leukocyte pipette up to 0.5 points. Add Turk solution to 11 points, shaken for 15-30 seconds, three drops discarded, next drop entered in count room. Leave it for 3 minutes and then count the total leukocyte cells in the microscope in 40X.

\section{Data processing}

Data obtained from leukocyte cell count, total leukocyte cell count, and relative lymph weight are statistically analyzed using one-way analysis of variance analysis (ANOVA) and then followed by Duncan Multiple Range Test using IBM SPSS 22 Version.

\section{RESULTS AND DISCUSSION}

The extraction process uses 3500 grams of fresh tapak liman leaves and produces simplicia of 1070 grams. Simplicia then made into powder before maceration so that contact between the simplicia and the solvent becomes wider and the solvent was easiest to penetrate into the plant cell and the withdrawal of the active substance is more perfect. ${ }^{12,13}$

Identification showed that the sample used plants form species Elephantopus scaber Linn, and family Asteraceae (Figure 1).

The extraction process used cold extraction method, maceration. The maceration method was chosen because of the simple process, economical, and not through the heating process and avoid the possibility of chemical changes of compounds. ${ }^{14}$ Ethanol $70 \%$ used to dissolve polar, semipolar or nonpolar compounds. It was less toxic than other organic solvents to test animals. ${ }^{1}$ In addition, another research report that ethanol extract of tapak liman leaves has wider bioactivity than tapak liman leaves extract that dissolves by another solvent such as methanol, acetone, hexane and ethyl acetate. ${ }^{15}$

Maceration was repeated three times so that the active substances that contained in the sample were perfectly extracted. The more of the maceration time, the more extracts could get. ${ }^{14}$ The maceration was shaken every day because of stagnant condition would make a decrease in the transfer of active substances of the sample. ${ }^{16}$ The ethanol extract 


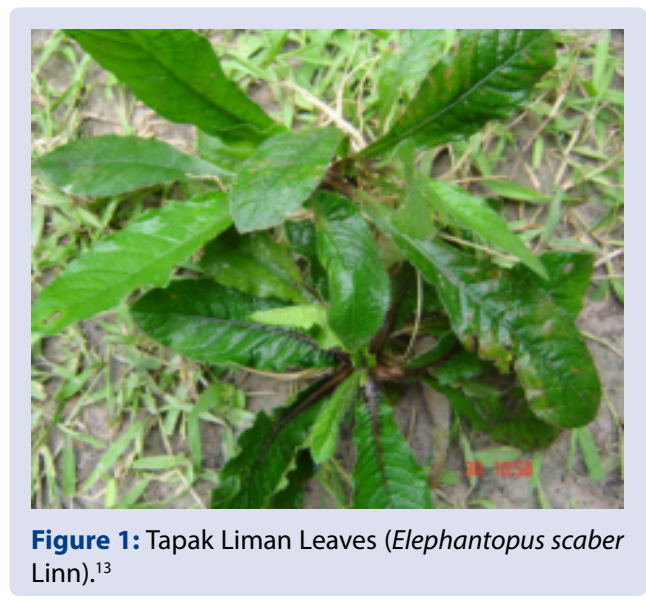

was concentrated using a rotary evaporator to obtained 35.087 gram extract and the percentage of rendement of ethanol extract of tapak liman leaves that obtained was $3.29 \%$. The rendement then examined to determine the percentage of the extract obtained from the sample and to determine the solvent's ability to attract active substances in the sample. ${ }^{11}$

The appropriate rendement percentage according to Indonesian Herbal Pharmacopoeia is not less than $2.7 \% .{ }^{16}$ There are several factors that influence the rendement such as; sample size and the type of solvent that used in the maceration process. The smaller sample size has a greater surface area of contact with the solvent so that the solvent interaction during the extraction process will be even greater. In addition, the solvents used in the maceration process must be in accordance with the sample used.

Demographic conditions, nutrition and the environment where plants grow are factors that cause differences in the content of chemical compounds. ${ }^{17}$ Characterization of extracts carried out includes specific and nonspecific parameters. Specific parameters carried out are organoleptic extracts (including shape, colour, smell, and taste) and thin layer chromatography (TLC) profiles. This examination aims to determine the shape, colour, smell, and taste of the extract so that it is easily recognizable a suitable with Indonesian Herbal Pharmacopoeia.

Based on the organoleptic test, the concentrate of extract tapak liman leaves (Elephantopus scaber Linn) was thick, blackish brown, odorless and bitter. These results are suitable according to a standard organoleptic extract of tapak liman in Indonesian Herbal Pharmacopoeia. Examination of the KLT profile was a qualitative test to determine identity compound in the extract. The comparative compound used a compound based on the Indonesian Herbal Pharmacopoeia which is deoxyelephantopin. Deoxyelephantopin compounds were obtained from Biota Sumatra Laboratories. ${ }^{11}$

Examination of TLC of ethanol extract of tapak liman leaves (Elephantopus scaber Linn) was obtained by extract Rf value of 0.68 and deoxyelephantopin $\mathrm{Rf}$ value of 0.68 (Figure 2). It showed that the extract of tapak liman leaves contains deoxyelephantopin compound and suitable with Rf value from Indonesian Herbal Pharmacopoeia. Nonspecific parameters that performed were determining drying shrinkage and total ash content. The purpose of it was to find out the limits maximum components that can evaporate such as water, essential oils and other compounds. ${ }^{18}$

Carbon Clearance method is a test of immunomodulatory activity by spectrophotometry by measuring carbon clearance in the blood of experimental animals at 3, 6, 9, 12 and 15 minutes. ${ }^{19}$ Carbon clearance method was chosen because it's accurate, fast, easy and economical. ${ }^{20}$
Immunomodulatory activity was test used experimental animal male white mice (Mus musculus L.). It was chosen because they were easy to obtain, easy to handle, physiologically similar to humans. ${ }^{21}$ The experimental animals that used have fulfilled the ethical approval by the Research Ethics Committee of Faculty of Medicine of Universitas Andalas with the approval number 032/KEP/FK/2018. Experimental animals are acclimated in a research room for a week to make that animal comforts with the experimental environment and to avoid stress during the treatment. Experimental animals that have different behavior must be separated so as not to affect the conditions of another experimental animal. ${ }^{19,22}$

Carbon clearance method is a spectrophotometric examination of nonspecific immunomodulatory activities by measuring carbon clearance in the blood of experimental animals at the time of testing at $3,6,9,12$ and 15 minutes. ${ }^{19}$ Chinese ink used to stable in the blood and does not inhibit in blood vessels and lungs. In addition, carbon also has the characteristics of an antigen because it is normally not present in the body. ${ }^{21,23,24}$ Carbon suspension was made using tween 80 with a $1 \%$ concentration and added physiological $\mathrm{NaCl} 0.9 \%$ to obtain a concentration of $64 \mathrm{mg} / \mathrm{ml}(6.4 \%)$. The use of physiological $\mathrm{NaCl}$ in the manufacture of suspensions same as the body condition (isotonic). ${ }^{25}$ To see the phagocytic effect of ethanol extract of tapak liman leaves, a standard curve was made between the carbon content in the blood and the absorbance value measured using a UV-Vis spectrophotometer at a wavelength of $650 \mathrm{~nm} .650 \mathrm{~nm}$ wavelength is an area of carbon uptake. ${ }^{21}$ From the results of determining the standard carbon curve obtained could be seen in Figure 3 with the regression equation $y=0.0064 \mathrm{x}+$ 0.0376 and $R^{2}=0.9901$. The value of the regression equation showed a linear relationship between carbon concentrations in the blood of mice and absorbance. ${ }^{26}$

Based on the average value of carbon absorbance in the blood in 650 $\mathrm{nm}$ spectrophotometer, there was a decrease in absorbance value in all groups given the tapak liman extract comparison with the control group. The decreasing value of carbon indicates the decreasing concentration of carbon that lives in the blood of mice. The carbon in the body will stimulate the formation of a non-specific immune system in the form of phagocyte cells. Phagocytic cells will be activated due to the stimulation of a non-specific immune response and quickly recognize the type of foreign antigen that enters the body then destroys and cleanses the antigen (carbon) from the bloodstream. ${ }^{19}$

Phagocytic constants are one of the phagocytic parameters, where the greater value of phagocytic constants, the higher the speed of carbon clearance so that faster phagocytic cells carry out phagocytic processes. ${ }^{27}$ The phagocytosis index value can be calculated after obtaining the phagocytic constant value. If the mean value phagocytosis index more

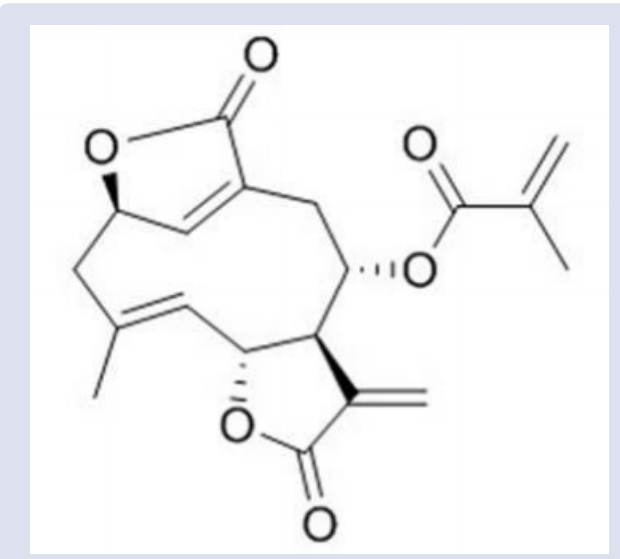

Figure 2: Chemical structure of deoxyelephantopin. 


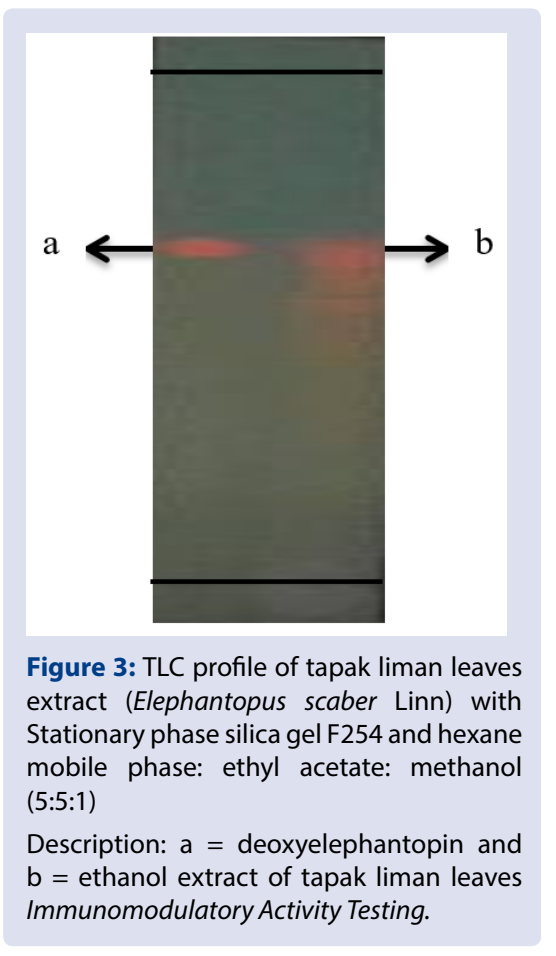

than 1 (IF>1) means that the substance has immunostimulatory activity. Conversely, if the mean value of the phagocytosis index is smaller than $1(\mathrm{IF}<1)$ means that the substance has immunosuppressant activity. ${ }^{28}$ In this experiment, the average phagocytosis index experimental group is more than 1 (IF>1) and could be seen in Figure 4. Based on the value of the phagocytosis index is a dose of 10,30 and a dose of $100 \mathrm{mg} / \mathrm{kg}$ is immunostimulant. The highest phagocytosis index value was shown by group dose of $100 \mathrm{mg} / \mathrm{kg} \mathrm{BB}$. Increased phagocytosis means destruction process of antigens is greater. ${ }^{27}$

The treatment showed the more doses that given the higher leukocyte could be produced. It present in Figure 5. The ANOVA Test result (Table 1) describe the effect of ethanol extract of tapak liman leaves (Elephantopus scaber Linn) was significantly increase the total of leukocyte $(p<0.01)$.

The DMRT result showed the effect of each dose of extract of tapak liman leaves was significantly increasing the total leukocyte despite the effect of $10 \mathrm{mg} / \mathrm{kg}$ dose and $30 \mathrm{mg} / \mathrm{kg}$ dose was not significantly different. It could be seen in Table 2 .

Administration of tapak liman leaves ethanol extract with increasing dosage could increase the number of segment neutrophil cells, lymphocytes, and monocyte cells. The complete results could be seen in Table 1. The increasing the value of neutrophil segment cells, monocytes and lymphocyte cells are one of the immunomodulatory activity parameters. Based on previous research the plants that potential as immunomodulator could activate immunocompetent cells to increase the body's immune system. Neutrophil cells and monocytes are firstline body defence cells in a nonspecific immune response because they function as phagocytic specialist cells which are very slow to move, eat and destroy immunogenic substances. ${ }^{29}$ Increasing lymphocyte cells show increased activity of specific immune responses. Lymphocyte cells consist of B lymphocytes and T lymphocytes. B lymphocyte cells will proliferate and differentiate to form plasma cells and memory cells. Plasma cells will form antibodies after contact with antigens. To establish antibodies, plasma cells cooperate with T lymphocytes. ${ }^{21}$ The comparison of effect extract tapak liman leaves could be seen in Figure 5.
According to the result of one-way ANOVA, the administration of tapak liman leaves extract on the percentage of leukocyte cells in each group had shown significantly different effect $(p<0.05)$ for eosinophils cells, lymphocytes, monocytes, and neutrophils stem meanwhile neutrophil segment cells showed a nonsignificant effect $(p>0.05)$.

The percentage of neutrophils was increased after the administration of ethanol extract tapak liman leaves. It could be seen in Table 4 that

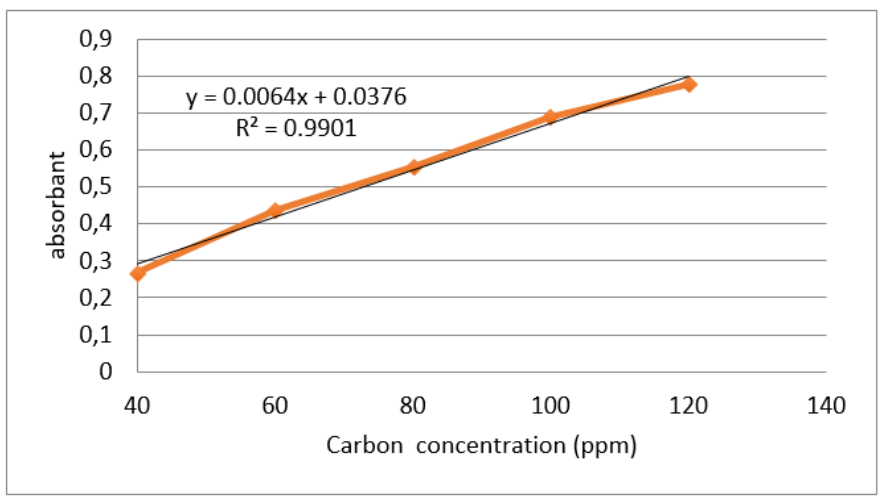

Figure 4: Calibration curve of carbon content in the blood of mice.

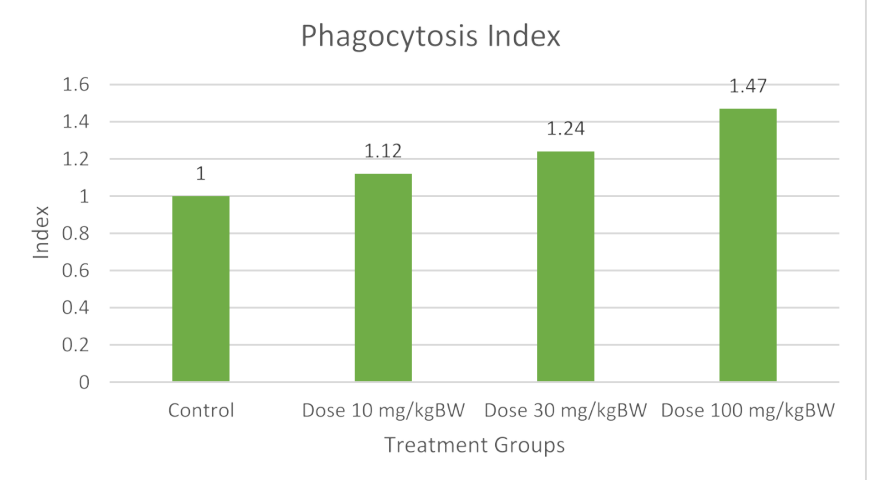

Figure 5: Graphic correlation between doses with phagocytic index values from male white mouse blood after administration of ethanol extract of tapak liman leaves (Elephantopus scaber Linn).

Table 1:The results of one-way ANOVA of total leukocyte cells in the after administration of ethanol extract of tapak liman leaves (Elephantopus scaber Linn).

\begin{tabular}{cccccc}
\hline & $\begin{array}{c}\text { Number of } \\
\text { squares }\end{array}$ & df & $\begin{array}{c}\text { Average } \\
\text { squared }\end{array}$ & F & Sig. \\
\hline $\begin{array}{c}\text { Between } \\
\text { Groups }\end{array}$ & 159249000.0 & 3 & $53083,000,000$ & 19.49 & 0,000 \\
$\begin{array}{c}\text { Within } \\
\text { Groups }\end{array}$ & 43573000.00 & 16 & 2723312,500 & & \\
Total & 202822000.0 & 19 & & & \\
\hline
\end{tabular}

Table 2: The results of DMRT of the treatment factor (dose) of total leukocyte cells after administration of ethanol extract of tapak liman leaves (Elephantopus scaber L.).

\begin{tabular}{ccccc}
\hline Group & N & \multicolumn{3}{c}{ Subset for alpha $=0.05$} \\
\cline { 3 - 5 } & & 1 & 2 & 3 \\
\hline Carrier control & 5 & 7400,0000 & & \\
Dosage of $10 \mathrm{mg} / \mathrm{kg}$ & 5 & & 10760,0000 & \\
Dosage of $30 \mathrm{mg} / \mathrm{kg}$ & 5 & & 11630,0000 & \\
Dosage of $100 \mathrm{mg} / \mathrm{kg}$ & 5 & & & 15330,0000 \\
Sig. & & 1,000 & 0,417 & 1,000 \\
\hline
\end{tabular}


Table 3: ANOVA analysis results on the percentage of leukocyte cell types after administration of ethanol extract of tapak liman leaves (Elephantopus scaber Linn).

\begin{tabular}{|c|c|c|c|c|c|c|}
\hline & & Sum of Squares & df & Mean Square & 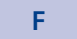 & Sig. \\
\hline \multirow[t]{3}{*}{ Eusinophyl } & Between Groups & 14.800 & 3 & 4.933 & 8.580 & 0.001 \\
\hline & Within groups & 9.200 & 16 & 0.575 & & \\
\hline & Total & 24.000 & 19 & & & \\
\hline \multirow[t]{3}{*}{ Lymphocytes } & Between Groups & 154.80 & 3 & 51.600 & 3.679 & 0.035 \\
\hline & Within Groups & 224.400 & 16 & 14.025 & & \\
\hline & Total & 379.200 & 19 & & & \\
\hline \multirow[t]{3}{*}{ Monocytes } & Between Groups & 56,950 & 3 & 18,983 & 22,33 & 0,000 \\
\hline & Within Groups & 13,600 & 16 & 0,850 & & \\
\hline & Total & 70,550 & 19 & & & \\
\hline \multirow[t]{3}{*}{ Neutrophils Stem } & Between Groups & 33,000 & 3 & 11,000 & 8,000 & 0,002 \\
\hline & Within Groups & 22,000 & 16 & 1,375 & & \\
\hline & Total & 55,000 & 19 & & & \\
\hline \multirow[t]{3}{*}{ Neutrophil Segment } & Between Groups & 19,350 & 3 & 6,450 & 0,343 & 0,795 \\
\hline & Within Groups & 301,200 & 16 & 18,825 & & \\
\hline & Total & 320,550 & 19 & & & \\
\hline
\end{tabular}

Table 4: The result of DMRT of the treatment factor (dose) of Eosinophil cells after administration of ethanol extract of tapak liman leaves (Elephantopus scaber Linn).

\begin{tabular}{ccccc}
\hline & & \multicolumn{3}{c}{ Subset for alpha $=0.05$} \\
\cline { 3 - 5 } & & $\mathbf{1}$ & $\mathbf{2}$ & 3 \\
\hline Dose $100 \mathrm{mg} / \mathrm{kg}$ & 5 & 0,8000 & & \\
Dose $30 \mathrm{mg} / \mathrm{kg}$ & 5 & 1,6000 & 1,6000 & \\
Dose $10 \mathrm{mg} / \mathrm{kg}$ & 5 & & 2,6000 & 2,6000 \\
Control & 5 & & & 3,0000 \\
Sig. & & 0,115 & 0,053 & 0,417 \\
\hline
\end{tabular}

Table 5: The result of DMRT of the treatment factor (dose) of Lymphocyte cells after administration of ethanol extract, tapak liman leaves (Elephantopus scaber Linn).

\begin{tabular}{cccc} 
& N & \multicolumn{2}{c}{ Subset for alpha $=0.05$} \\
\cline { 3 - 4 } & & 1 & 2 \\
\hline Control & 5 & 29,4000 & \\
Dose $10 \mathrm{mg} / \mathrm{kg}$ & 5 & 32,6000 & 32,6000 \\
Dose $30 \mathrm{mg} / \mathrm{kg}$ & 5 & 33,6000 & 33,6000 \\
Dose $100 \mathrm{mg} / \mathrm{kg}$ & 5 & & 37,2000 \\
Sig. & & 0,111 & 0,083 \\
\hline
\end{tabular}

showed the dose $100 \mathrm{mg} / \mathrm{kg}$ could decrease the percentage while in another dose still the same.

The percentage of total lymphocyte and eosinophil were increased while other cells were decreased. It means the effect of extract tapak liman leaves was better on the specific immune system. The increasing of lymphocyte and eosinophil would protect the body from infection attack. Lymphocyte $\mathrm{T}$ in thymus gland would differentiate and proliferate be Natural Killer cell (NK Cell) and this cell.

Lymphocyte $\mathrm{T}$ at thymus gland will differentiate and proliferate be Natural Killer Cell (NK Cell) that responsibility directly in the process to destroy intracellular infection (virus and bacteria) and neoplasm through apoptosis, perforin, and granzymes. Specifically, lymphocyte would differentiate and proliferate be $\mathrm{T} \mathrm{CD}^{+} 8$ cell then differentiate and proliferate again be cytotoxic $t$ cells $\left(\mathrm{T}_{\mathrm{c}}\right)$ that has a role that responsibility directly in the process to destroy intracellular infection (virus and bacteria) and neoplasm. ${ }^{30,31}$

The activity of tapak liman leaves extract on the percentage of monocyte cells from ANOVA analysis showed a very significant difference $(p<0.05)$. Duncan's test (Table 6), was seen as very significant $(p<0.05)$.
Monocyte cells circulating in the blood usually for 12 hours and then will settle into macrophages. Macrophage cells which are already on the network is a professional phagocytic cell and to a very large $m$ Ampuan phagocytosis in destroying foreign particles when compared with the other phagocytic cells. ${ }^{30,31}$ The occurrence of a decrease in monocytes in the blood indicates the process of macrophage cell formation increases and this is evidenced by the high value of the phagocytosis index $(>1)$.

Based on the DMRT result, the effect of reducing the number of stem neutrophil cell percentages was significantly different. Meanwhile, the neutrophil segment was not affected by the treatment. The greater the dose is given, the fewer neutrophil stem cells, while the effect of $10 \mathrm{mg} / \mathrm{kg}$ and $30 \mathrm{mg} / \mathrm{kgBB}$ doses were nonsignificant. The results of Duncan's test analysis could be seen in Table 4 . Stem neutrophil cells are neutrophil cells that are young and will proliferate and differentiate into segment neutrophil cells. The faster the ripening process, then the bushes in many neutrophil cells are formed and of course, the phagocytosis process will increase. ${ }^{30,32}$

Segmented neutrophil cells are the type of neutrophil cells that act to destroy antigens. Increased and high activity of neutrophil cells tends to be detrimental to the body's physiological system because the 
phagocytic activity of neutrophil cells tends to cause inflammatory reactions. ${ }^{30,32}$

The Lymph was grouped in secondary lymphoid. In this organ, antigen and lymphocyte will interact with each other so that lymphocyte will differentiate and proliferate be plasma cell and produce antibody. The more active of proliferate process of lymphocyte that would increase lymph relative weigh. It could be seen in Figure 6.

The result of ANOVA analysis showed a significant difference $(p<0.05)$ relative lymph weights in each group. It could be seen in Table 9 and the DMRT results are as shown in Table 10. The DMRT result showed all groups in different subsets. That means increasing of the activity of lymphocyte $B$ to produce antibodies in lymph due to the administration of ethanol extract of tapak liman leaves has an effect on increasing lymph weight and immunomodulatory activity. ${ }^{21}$ The increasing of lymph weight in this study was also followed by an increase in lymphocyte cells because the lymphatic organ occurs differentiation and proliferation of lymphocytes resulting in lymphatic enlargement. ${ }^{33}$

Tapak Liman leaves has been reported to contain sesquiterpene lactone compounds such as deoxyelephantopin, isodeoxyelephantopin, and scabertopin..$^{34}$ In addition, research results have also been reported that antioxidant compounds found in a plant can increase the body's immune system by increasing the number of leukocyte cells. ${ }^{35}$ Based on the research it can be concluded that the ethanol extract of tapak liman leaves has immunostimulatory activity. This study should be continued to determine the effect of an extract of tapak liman leaves on activity

Table 6: The result of DMRT of the treatment factor (dose) on monocytes after administration of ethanol extract of tapak liman leaves (Elephantopus scaber Linn).

\begin{tabular}{|c|c|c|c|c|}
\hline \multirow{2}{*}{ Group } & \multirow{2}{*}{$\mathbf{N}$} & \multicolumn{3}{|c|}{ Subset for alpha $=0.05$} \\
\hline & & 1 & 2 & 3 \\
\hline $\begin{array}{c}\text { Dosage of } 100 \mathrm{mg} \\
\qquad / \mathrm{kg}\end{array}$ & 5 & 1,6000 & & \\
\hline $\begin{array}{l}\text { Dosage of } 30 \mathrm{mg} \\
\quad / \mathrm{kg}\end{array}$ & 5 & 2,6000 & & \\
\hline $\begin{array}{l}\text { Dosage of } 10 \mathrm{mg} \\
\quad / \mathrm{kg}\end{array}$ & 5 & & 4,4000 & \\
\hline Control & 5 & & & 6,0000 \\
\hline Sig. & & 0,106 & 1,000 & 1,000 \\
\hline
\end{tabular}

Table 7: The result of DMRT of the treatment factor (dose) of neutrophil stem cells after administration of ethanol extract, tapak liman leaves (Elephantopus scaber Linn).

\begin{tabular}{ccccc}
\hline Group & N & \multicolumn{3}{c}{ Subset for alpha $=0.05$} \\
\cline { 3 - 5 } & & 1 & 2 & 3 \\
\hline Dosage of $100 \mathrm{mg} / \mathrm{kg}$ & 5 & 1,6000 & & \\
Dosage of $10 \mathrm{mg} / \mathrm{kg}$ & 5 & & 3,4000 & \\
Dosage of $30 \mathrm{mg} / \mathrm{kg}$ & 5 & & 3,8000 & 3,8000 \\
Control & 5 & & & 5.2000 \\
Sig. & & 1,000 & 0,597 & 0,077 \\
\end{tabular}

Table 8: The result of DMRT of treatment factors (dose) on segmented neutrophil cell after administration of ethanol extract, tapak liman leaves ( Elephantopus scaber Linn)

\begin{tabular}{ccc} 
Group & N & Subset for alpha $=0.05$ \\
\cline { 3 - 3 } & & 5 \\
Control & 5 & 56.4000 \\
Dosage of $10 \mathrm{mg} / \mathrm{kg}$ & 5 & 57.0000 \\
Dosage of $30 \mathrm{mg} / \mathrm{kg}$ & 5 & 58.4000 \\
Dosage of $100 \mathrm{mg} / \mathrm{kg}$ & & 58.8000 \\
Sig. & & 0.433 \\
\hline
\end{tabular}

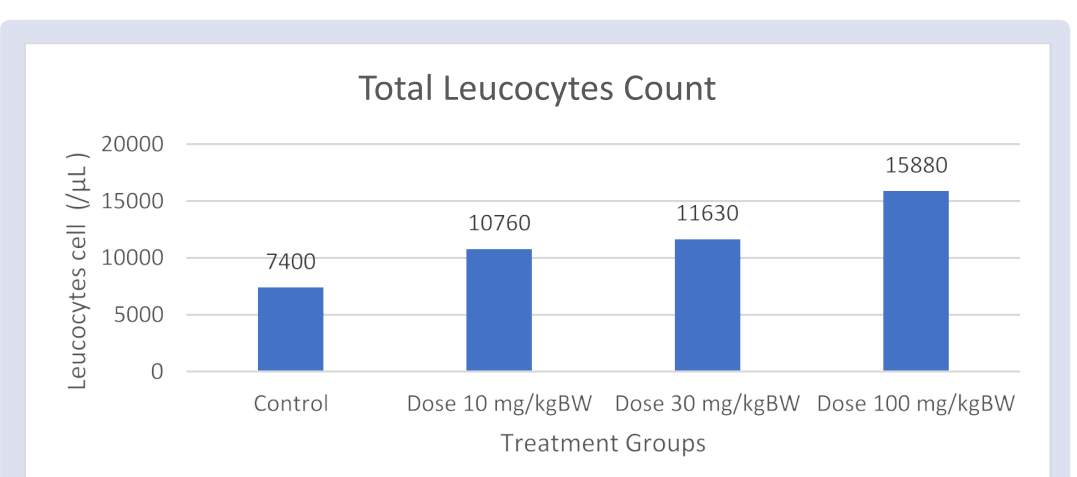

Figure 6: Graphic correlation between total leukocyte cells with treatment group after administration of the extracted ethanol leaves liman leaves (Elephantopus scaber Linn). 


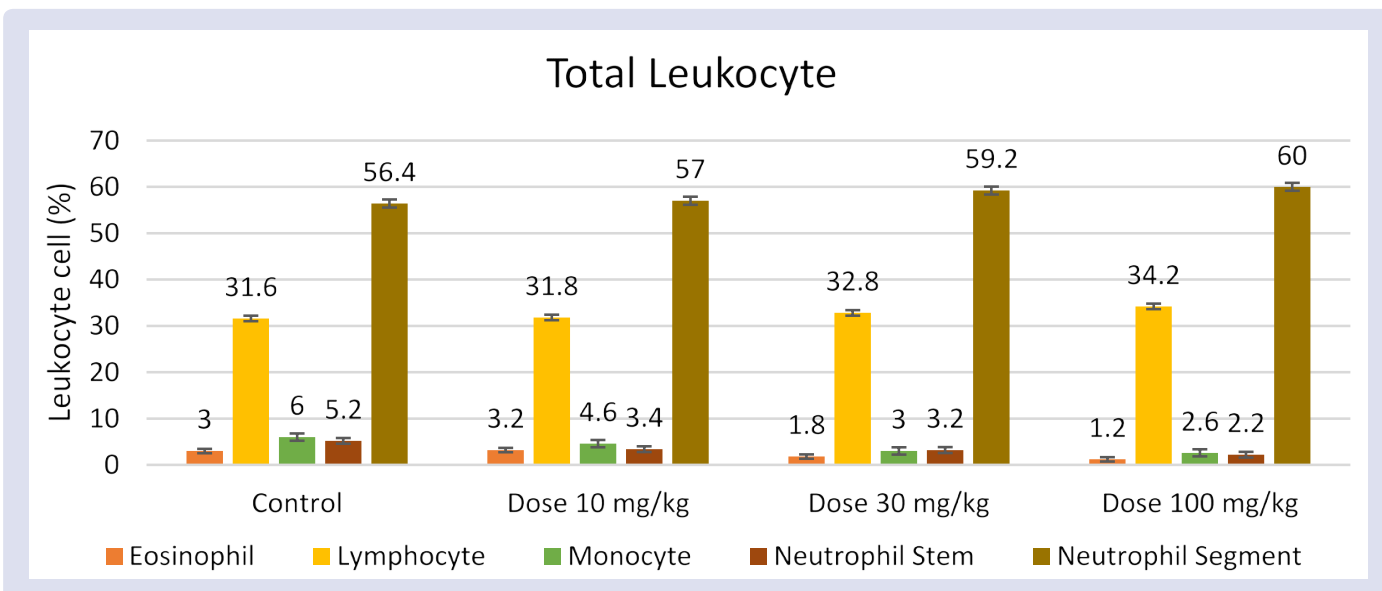

Figure 7: Graphic correlation between the percentage of leukocyte cell types and the treatment group after giving ethanol extract of tapak liman leaves (Elephantopus scaber Linn).

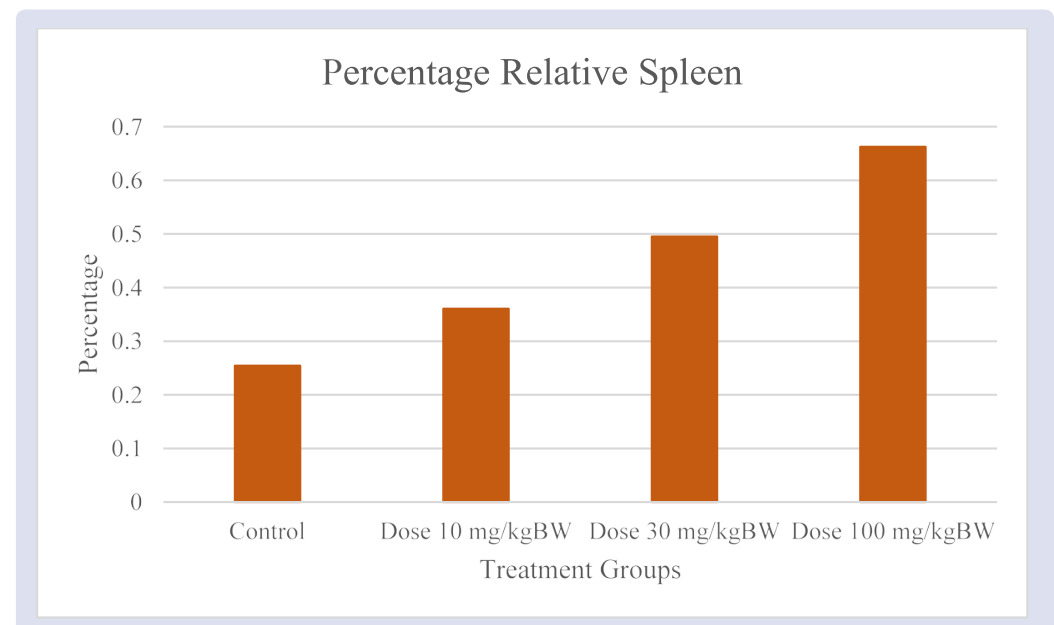

Figure 8: Graphic correlation between the percentage of relative lymph weight with treatment group after ethanol extract of tapak liman leaves (Elephantopus scaber Linn).

and capacity of macrophage cell, especially professional phagocyte, also cytokine that influence in it.

\section{CONCLUSION}

After the immunostimulant activity test was conducted to on extract of tapak liman leaves (Elephantopus scaber Linn) with the carbon clearance method on white male mice, we can conclude that tapak liman leaves extract (Elephantopus scaber Linn) can improve the immunity of white male mice.

\section{ACKNOWLEDGMENTS}

The authors would like to deliver a special appreciation to the Rector of Universitas Andalas for the financial support based on Professor Research Grant of Universitas Andalas.

\section{CONFLICTS OF INTEREST}

The author(s) declare(s) that there is no conflict of interest regarding the publication of this article.

\section{REFERENCES}

1. Azizah, Masayu, Wiwik Wiraningsih, Ema Ratna Sari. Immunomodulatory effect of ethanol extract of pineapple rind(Ananas comosus L. Merr) on white male mice with carbon clearance. Indonesian Journal of Applied Sciences. 2017;2.p
2. WHO (World Health Organization). Available online: http://www.who.int/topics/ infectious_diseases/factsheets/en/. (accessed on 12 November 2018).

3. Radji M. Immunology \& Virology, Ed contents of revision; PT. ISFI Publishing Jakarta, 2015.

4. Subowo, Clinical Immunology; Space: Bandung, 1993.

5. Ismail, Syed, and Mohammed Asad. Immunomodulatory activity of Acacia catechu. Indian J Physiol Pharmacol. 2009;53:25-33.

6. Baratawidjaja KG, Rengganis I. Basic immunology. 8th ed. jakarta, FKUI 2009:557-620

7. Savant, Chetan, Anand Rao Kulkarni, Basheerahmed Abdulaziz Mannasaheb, Rahul G. Immunomostimulant phytoconstituents from Mangifera indica L. bark oil. J Phytopharmacol. 2014;3:139-48.

8. Solikin, Solikin. Autecologi Elephantopus scaber L. in Kebun Raya Purwodadi. Bioeksperimen: Jurnal Penelitian Biologi. 2015;1:24-32.

9. Kabiru, Abubakar, and Lip Yee Por. Elephantopus species: traditional uses, pharmacological actions and chemical composition. Adv Life Sci Technol. 2013;15:6-13.

10. Aldi Y, Dillasamola D, Rifa N. Effect of Ethanol from Extract of Tapak Liman Leaves (Elephantopus scaber Linn.) on Hematopoiesis of Anemia Mice. International Journal of Pharmaceutical Research \& Allied Sciences. 2019;8(2)

11. Republic of Indonesia ministry of health. Indonesian herbal pharmacopoeia First edition. Republic of Indonesia ministry of health. Jakarta. 2008.

12. Yanti AR. Immunostimulation effect test of water extract of black cumin seeds (Nigella sativa L.) in White Mice (Mus musculus L.) in Sore Carbon. Farmasains. 2010;1(2):76-9.

13. Association of Southeast Asian Nations, and Rasadah Mat Ali. ASEAN herbal and medicinal plants. ASEAN Secretariat, 2010. 
14. Yulianingtyas A, Kurmartono B. Optimization of solvent volume and time of maceration of extracting starfruit leaves flavonoids (Averrhoa Balimbi L.). Journal of Chemical Engineering. 2016;10(2):58-64.

15. Ho, Wan Yong, Huynh Ky, Swee Keong Yeap, Raha Abdul Rahim, Abdul Rahman Omar, et al. Traditional practice, bioactivities and commercialization potential of Elephantopus scaber Linn. 2009.

16. Voight R. Voigt's Pharmaceutical Technology. 5th ed.; Universitas Gajah Mada Press: Yogyakarta Indonesia, 1994.

17. Hanani E. Phytochemical Analysis; ECG Medicine Books: Jakarta Indonesia, 2014.

18. Isnawati Ani, Mariana Raini, Ondri Dwi Sampurno, D Mutiatikum, Lucie Widowati, Retno Gitawati. Characterization of 3 types gambir extract (Uncaria gambir Roxb) from Sumatera Barat. Buletin Penelitian Kesehatan. 2012;40:201-8.

19. Zilhadia, Wiraswati Y, Chairul. Gambir Immunomodulatory effect test for gambir catechins (Uncaria gambier Roxb.) Using the In vitro carbon clearing parameters. Indonesian Natural Materials Journal. 2012;8(3):181-6.

20. Ponkshe CA, Madhavi M. Indap. In vivo and in vitro evaluation for immunomodulatory activity of three marine animal extracts with reference to phagocytosis. 2002.

21. Aldi $Y$, Dillasamola $D$, Friadi, Purnamasari R. Immunomodulatory effect of ethanol extract skin of purple sweet potato (/pomoea batatas Lin.) With carbon clearance method and the number of leukocytes. Research Jornal of Pharmaceutical Biological and Chemical Sciences. 2016;7(3):1192-9.

22. Almahdi A. Padang Experimental Teratology; Universitas Andalas; 2012.

23. Nursida, Hardianti B, Lebang JS, Utami YR. Activity test of Moringa oleifera Lam suspension leaves preparation for phagocytosis activity of male mice (Mus musculus). Journal of Pharmaceutical and Medicinal Sciences. 2016;1(1):12-7.

24. Rahmawati, Irma, Yani Triyani, Rika Nilapsari. Biji Cempedak (Artocarpus integrifolia) terhadap Aktivitas Fagositosis pada Mencit Jantan Galur Swiss. Global Medical \& Health Communication (GMHC). 2014;2:55-9.
25. Zabriskie, John B., ed. Essential clinical immunology. Cambridge University Press,2009.

26. Alfitasari DA, Kusuma AM, Judge ZR. Immunomodulatory activities ethanol extracts of shallots (Allium cepa L.) against non-specific immune repons in male mice balb / C strains with carbon clearance method. 2017;34(2):75-9

27. Wagner $\mathrm{H}$, Jurcic K. Assays for immunomodulation and effects on mediators of inflammation. Methods in Plant Biochemistry. 1991;6:195-217.

28. Kresno SB. Laboratory immunology diagnosis and procedures. 5th Ed. Universitas Indonesia; Jakarta Indonesia. 2010.

29. Purnamasari R. Polisakarida krestin from Coriolus versicolor on differential count of leukocytes on Mycobacterium tuberculosis mice. BIOTROPIC The Journal of Tropical Biology. 2017;1(2):16-30.

30. Abbas, Abul K, Andrew HH Lichtman, Shiv Pillai. Cellular and molecular immunology E-book. Elsevier Health Sciences,2014.

31. Bratawidjaja KC, Rengganis I. Non-specific immune system cells, macrophage phagocytic system. In: Wachjuni, Ambara, Prasna P, Farah $\mathrm{P}$ editor. Basic Immunology. 9th Edition. Jakarta: FKUI Publisher Center; 2010;57-90.

32. Burtis, Carl A, David E Bruns. Tietz Fundamentals of Clinical Chemistry and Molecular Diagnostics-E-Book. Elsevier Health Sciences,2014.

33. Aldi Yufri, Suhatri Suhatri. Activity of ethanol extract jintan hitam (Nigella sativa Linn.) on antibodi titer and leukosit count of white male mice. SCIENTIAJournal of Pharmacy and Health. 2015;1(1):35-41.

34. Hiradeve, Sachin M, Vinod D Rangari. Elephantopus scaber Linn.: A review on its ethnomedical, phytochemical and pharmacological profile. Journal of Applied Biomedicine. 2014;12(2):49-61.

35. Hussain Kashif, Zafar Iqbal, Rao Zahid Abbas, Muhammad Kasib Khan, Muhammad Kashif Saleemi. Immunomodulatory activity of glycyrrhiza glabra extract against mixed eimeria infection in chickens. International Journal of Agriculture \& Biology. 2017;19(4).

\section{GRAPHICAL ABSTRACT}

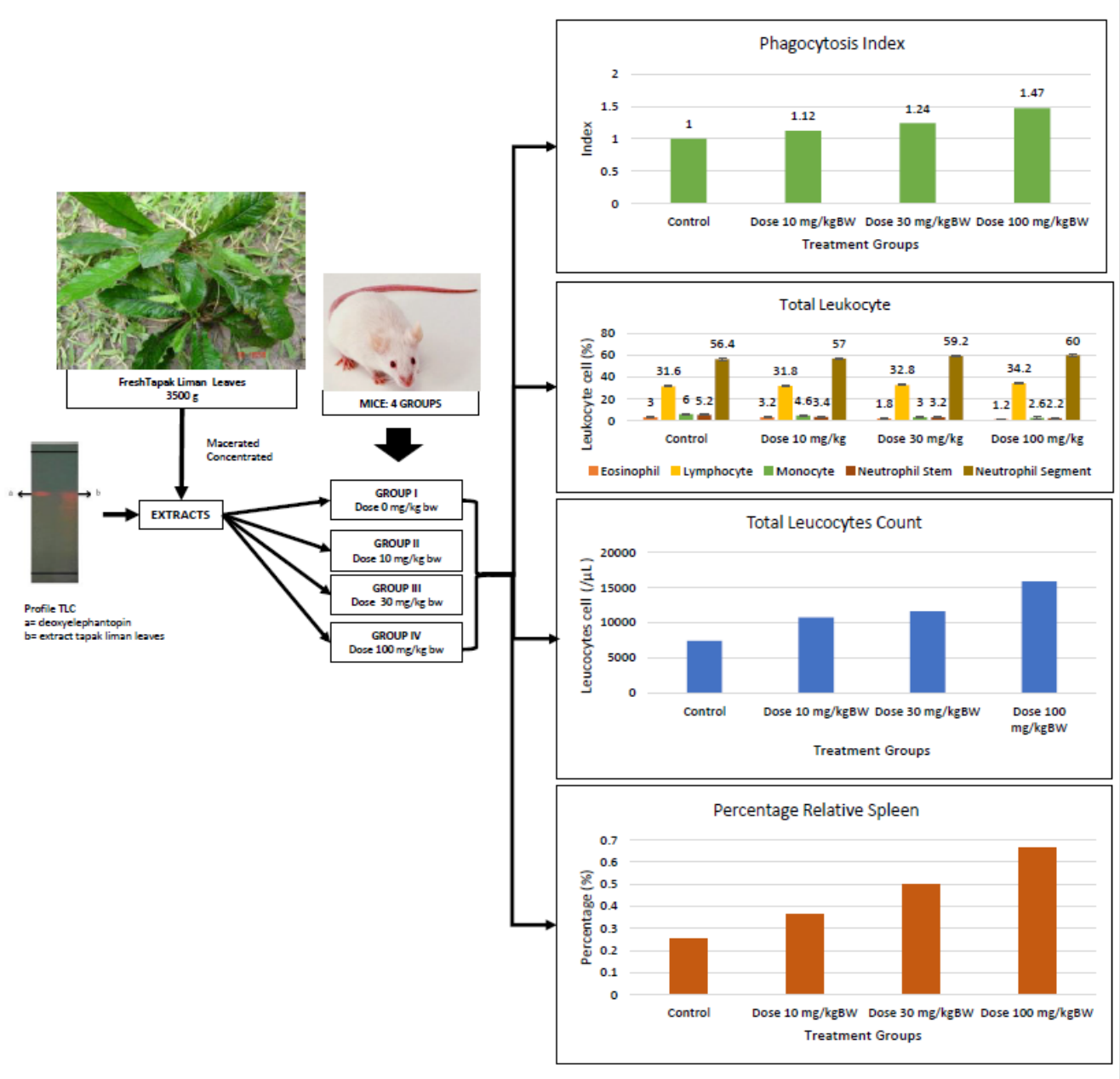




\section{SUMMARY}

Tresearch on extracts from Elephantopus scaber Linn on immonumodulator activity using carbon clearance method has been carried out, which measures the total number and percentage of leukocytes, as well as the relative spleen weight. Tapan Liman leaves (Elephantopus scaber Linn) were tested in the form of extracts that had been standardized according to Herbal Pharmacopea Indonesia. The dosage is given daily for 7 days orally at doses of 10, 30 and $100 \mathrm{mg} / \mathrm{kg}$ body weight. The administration of extract of tapak liman leaves (Elephantopus scaber Linn) dose of 10, 30 and $100 \mathrm{mg} / \mathrm{kgBW}$ increase the total number of leukocyte cells. The administration of ethanol extract of tapak liman leaves (Elephantopus scaber Linn) at doses of 10 , 30 and $100 \mathrm{mg} / \mathrm{kg}$ can increase the percentage of the neutrophil segment and lymphocyte cell types and reduce the percentage of monocyte cells.

\section{ABOUT AUTHORS}

- Dr. Drs. Yufri Aldi, M.S.i., Apt.: Currently as a lecturer at the Faculty of Pharmacy, University Andalas. Graduated from Faculty of Pharmacy Universitas Andalas in 1989, then Master Program in 1994 at School of Pharmacy Institut Teknlogi Bandung (ITB Bandung) and Doctoral Program in Department Biomedical, Faculty of Medicine, University Andalas in 2013. The research and expertise are in Farmaco-Immunology. Currently working as an assistant to the First Vice-Rector of Universitas Andalas and Head of the Department Doctoral Programme Pharmacy of Faculty of Pharmacy, Universitas Andalas.

- Dwisari Dillasamola,M.Farm, Apt: Currently as a lecturer Faculty of Pharmacy, Universitas Andalas. Graduated from Faculty of Pharmacy Universitas Andalas in 2004, then Master Program at Faculty of Pharmacy Universitas Andalas in 2011. The research and expertise are in Farmaco-Immunology. Research expertise in Farmaco-Immunology and Clinical-pharmacy.

- Gita Rahma Yanti: She is graduated from Faculty of Pharmacy Universitas Andalas who have been involved in assisting in the study of Immunomodulator Activity of Ethanol Extract of Tapak Liman Leaves (Elephantopus scaber Linn.)

Cite this article: AldiY, Dillasamola S, Yanti GR. Immunomodulator Activity of Ethanol Extract of Tapak Liman Leaves (Elephantopus scaber Linn.). Pharmacog J. 2019;11(6)Suppl:1419-27. 